\title{
GENETIC STUDIES ON SOME QUANTITATIVE TRAITS IN PEA 2. INHERITANCE OF NUMBER OF DAYS TO FLOWERING AND SOME POD CHARACTERISTICS
}

\author{
KHALIL, E. M. E. A., A. H. HUSSEIN and A. A. HAMED
}

Veg. Res. Dept., Horticulture Res. Inst., ARC, Giza, Egypt.

(Manuscript received 5 July 2015)

\begin{abstract}
$\mathrm{T}$ his study was conducted in Horticulture Research Institute during the period from 2012 to 2015 to study the inheritance of some garden pea economic characters, viz., number of days to flowering, pod length, number of seeds/pod, seed weight and shelling percentage. Four garden pea cvs., viz, Master, Perfection 57, Prism and Twin were chosen to produce 3 crosses and their reciprocals. Results showed that maternal effect was absence in all studied characters. Over dominance and complete dominance was detected for high shelling percentage. Complete dominance towards high parent and absence of dominance were found on number of seeds/pod. Partial dominance was detected for late flowering parents in all the studied crosses. High pod length and high seed weight were dominant in some studied crosses and the opposite found in the others. Positive heterosis over the better parent was found in all the studied crosses for number of days to flowering (based on the early flowering parent) trait, meanwhile, Negative heterosis was detected in all studied crosses for pod length and seed weight traits. For number of seeds/pod and shelling percentage traits, positive hetrosis was found in one cross and the opposite was found in the other. Minimum number of estimated genes was one for number of days to flowering, number of seeds/pod and shelling percentage traits, while it was 3-18 for pod length and 1-6 for seed weight. Broad sense heritability estimates were $93.47 \%-94.74 \%$ for number of days to flowering, 31.47\%-66.38\% for pod length, $29.22 \%-59.78$ for number of seeds/pod, $23.88 \%-42.23 \%$ for seed weight and $41.41 \%-58.42 \%$ for shelling percentage.

Key words: Pisum sativum, Dominance, Heterosis, Number of genes, Heritability, Earliness, Pod length, Shelling percentage.
\end{abstract}

\section{INTRODUCTION}

Garden pea, Pisum sativum L., is one of the most important popular vegetable crops during winter in Egypt. Crop improvement depends upon the magnitude of genetic variability and the extent to which desirable traits are heritable. The improvement of pea quality depends upon a better understanding of the gene type action which controlling the earliness and pod characters. Recently there are intensive efforts for improvement quality of peas in Egypt through breeding procedures 
depending mainly on the presence of genetic differences that permits effective selection. Hybridization is considered an effective factor for inducing variability.

Noser (2002) found that maternal effect existed for number of days to flowering trait only in one out of the six studied crosses of pea. Also, maternal effect was found only in one out of three studied crosses of garden peas (Hamed, 2005). Partial dominance towards the late flowering parent was detected in pea crosses (Hamed, 2005 and Abbas, 2012). Meanwhile, different types of dominance were obtained by Noser (2002). Also, Sood and Kalia (2006) found complete and over dominance for this trait. Significant positive heterosis -based on early parent- was observed in all the crosses for days to flowering (Hamed, 2005). While, Noser (2002) found negative heterosis in some crosses and positive heterosis values in the others. Minimum number of genes (MNG) controlling number of days to flowering was estimated as a single gene (Rajaneesh and Ram, 2001), one to two pairs of genes (Noser, 2002) and two to seven pairs of genes (Hamed, 2005). High broad sense heritability (BSH) estimates were obtained by Bora et al. (2009) and Kumari et al. (2009). Meanwhile, it ranged from moderate to low (Abbas, 2012). Broad sense heritability was estimated as $65.64 \%$ to $94.23 \%$ (Noser, 2002), $63.4 \%$ to $77.5 \%$ (Hamed, 2005) and 98.0\% (Galal, 2014).

Hamed (2005) detected no-significant differences between reciprocal crosses for pod length in pea. Complete and partial dominance of the highest parent was detected for this character (Hamed, 2005). Hamed (2005) found extremely low positive heterosis $(1.6 \%)$ for pod length in one out of four studied pea crosses, meanwhile, negative heterosis values were obtained in other studied crosses for this trait which ranged from $-11.7 \%$ to $-1.9 \%$. Minimum number of genes controlling pod length trait was 1-3 pairs of genes (Hamed, 2005). Broad sense heritability was high as reported by El-Dakkak et al. (2014). On the contrary, Estimates of BSH for this character ranged from $44.4 \%$ to $64.8 \%$ indicating moderate environmental effect on this trait (Hamed, 2005). Also, Kumari et al. (2009) and Singh et al. (2011) found moderate to high heritability for this trait on peas. Chaudhary and Sharma (2003), Gupta et al. (2006),Sharma et al. (2011), and Galal (2014) estimated it as 35\%, $42.25 \%, 89.96 \%$ and $88-93 \%$ on peas, respectively.

Maternal effect existed on number of seeds/pod trait only in one out of six crosses as mentioned by Noser (2002). Meanwhile, Hamed (2005) indicated that no maternal effect for this trait was found. Noser (2002) found different types of dominance, viz., over dominance, complete dominance and partial dominance towards the high parent and complete dominance towards the lowest parent for this trait. Meanwhile, partial dominance towards the high parent was noted by Hamed (2005). 
Also, Sood and Kalia (2006) found partial and over dominance for this trait. Positive heterosis over the better parent was found in three crosses, meanwhile, three other crosses exhibited negative heterosis on number of seeds/ pod trait (Noser, 2002). Hamed (2005) exhibited low negative high-parent heterosis values estimated as $6.6 \%$ and $-7.9 \%$ for this trait. However, Kosev et al. (2012) obtained positive heterosis estimated as $42.09 \%$. Noser (2002) found that minimum number of genes controlling this trait which was 1-7 pairs of genes. Meanwhile, Hamed (2005) estimated it as a single gene. Broad sense heritability was moderate to high (Chaudhary and Sharma, 2003, Hamed, 2005, Gupta et al., 2006 and El-Dakkak et al., 2014) and high (Galal, 2014). However, Noser (2002) found that BSH for this trait ranged from $14.67 \%$ to $43.47 \%$ on peas.

Noser (2002) and Hamed (2005) found that maternal effect was absent in the inheritance of seed weight in the all studied pea crosses. Noser (2002) revealed that complete dominance of the highest parent was found in two crosses and on the contrary, complete dominance of the lowest parent was observed in three crosses and partial dominance of the lowest parent was detected in one cross. In the same direction, Hamed (2005) found partial dominance of the highest parent in some crosses and partial dominance of the lowest parent in others. Negative high-parent heterosis values were estimated for seed weight in the all studied crosses which ranged from $\quad-17.5 \%$ to $-10.3 \%$ (Hamed, 2005). Noser (2002) found positive heterosis, based on the highest parent, estimated as $9.1 \%$ and $3.5 \%$ in two crosses, meanwhile, negative heterosis values ranged from $-21.1 \%$ to $-12.1 \%$ was detected in four other crosses. Minimum number of genes controlling this trait was estimated as 1-2 pairs of genes (Noser, 2002 and Hamed, 2005). Broad sense heritability estimated for seed weight was high (Chaudhary and Sharma, 2003 and Singh et al., 2011). Meanwhile, it was ranged from $18.18 \%$ to $94.29 \%$ (Noser, 2002), from $11.9 \%$ to $24.5 \%$ (Hamed, 2005) and from $47.10 \%$ to $99.21 \%$ (El-Dakkak et al., 2014).

Noser (2002) and Hamed (2005) found that maternal effect for shelling percentage trait was not observed in any one of the studied crosses. Noser (2002) found complete dominance of the high parent in all the studied crosses. Hamed (2005) indicated that over dominance and complete dominance of the best parent were obtained. Also, Sood and Kalia (2006) and Abbas (2012) found that shelling percentage was controlled by over dominance. Low positive heterosis, based on the highest parent, was estimated for shelling percentage trait in two crosses, while four other crosses gave negative heterosis (Noser, 2002). Meanwhile, Ravinder et al. (2003) found significant economic heterosis over commercial parent for shelling percentage. Hamed (2005) indicated that, three out of the 4 studied crosses exhibited 
positive high-parent heterosis for shelling percentage as ranged from $1.5 \%$ to $27.6 \%$. On the contrary, one hybrid exhibited very low negative heterosis. Minimum number of genes governing shelling percentage was one pair in the all crosses studied by Noser (2002). It was estimated as one to three pairs of genes (Hamed, 2005 and Abbas, 2012). Broad sense heritability estimated for seed weight was low to moderate (Noser, 2002 and Hamed, 2005), meanwhile, Gupta et al. (2006), Kumari et al. (2009), and Sharma et al. (2011) indicated that it was moderate. However, Chaudhary and Sharma (2003) estimated it as $97 \%$.

The main objective of our present investigation was to study the inheritance of some economic characters of garden pea to produce and select new lines with good characters which can be included in subsequent breeding programs.

\section{MATERIALS AND METHODS}

This study was conducted during the period from 2012 to 2015. Production and evaluation of genetic populations were carried out in the open field of Kaha Vegetable Research Farm, Kalubia Governorate, Egypt. Four garden pea cvs., viz, Master, Perfection 57, Prism and Twin were chosen for genetic studies based on their performance as shown in Table 1.

Table 1. Description of studied cultivars.

\begin{tabular}{|c|c|c|c|c|c|c|c|}
\hline Cultivar & $\begin{array}{c}\text { Stem } \\
\text { length }\end{array}$ & Leaf type & $\begin{array}{c}\text { Flowering as } \\
\text { no. of days } \\
\text { from sowing }\end{array}$ & $\begin{array}{c}\text { No. of nods } \\
\text { to the first } \\
\text { pod }\end{array}$ & $\begin{array}{c}\text { No. } \\
\text { pods/node }\end{array}$ & Pod color & Seed size \\
\hline Master & Short & Conventional & 44 & $7-8$ & $1-2$ & Green & Medium \\
\hline Perfection 57 & Medium & Leafless & 55 & $13-14$ & $2-3$ & Green & Medium \\
\hline Prism & Short & Leafless & 60 & $13-14$ & 2 & Dark green & Medium \\
\hline Twin & Medium & Conventional & 60 & $13-14$ & $2-3$ & Green & Small \\
\hline
\end{tabular}

Seeds of these cultivars were sown in the open field at Kaha on mid October, 2012. Three crosses, viz., Master $\times$ Perfection 57, Master $\times$ Prism and Master $\times$ Twin and their reciprocals were produced. Seeds of the straight $F_{1}$ crosses were sown on mid October, 2013. Flowers on plants were left for selfing to produce $F_{2}$ seeds. In the same time, production of $F_{1}$ seeds was completed.

Evaluation of genetic populations was carried out at Kaha. Seeds of parental, $F_{1}$, $F_{1} r$ and $F_{2}$ populations of each of the three crosses were sown on mid October, 2014 in a randomized complete block design with three replicates. Each replicate consisted of one row for every non-segregating population, i.e., parents, $F_{1}$ and their reciprocals and three rows for each $F_{2}$. Each row was $3.0 \mathrm{~m}$ long and $0.7 \mathrm{~m}$ wide. Individual 
seeds were sown $15 \mathrm{~cm}$ apart. Cultural practices such as irrigation, chemical fertilization, and disease and insect control were practiced as commonly followed in this district.

Data were recorded on individual plants for the different populations in each cross for number of days to flowering, pod length, number of seeds/pod, seed weight and shelling percentage. Characters were studied only in the crosses which their parents were significantly different in such characters.

Data were recorded as follow:

Number of days to flowering was measured as the number of days from sowing until first flower anthesis. Pod length was estimated as the mean of five pods/plant in $\mathrm{cm}$. Number of seeds/pod was estimated as the mean number of seeds per five pods/plant. Seed weight was calculated by dividing the green seeds weight of five pods by their number in $\mathrm{g}$. Shelling percentage was calculated for five pods/ plant as follows: Shelling percentage $=($ Seeds weight/total pod weight $) \times 100$.

\section{Genetic parameters estimated}

Maternal effect was estimated by measuring the significance of difference between each $F_{1}$ mean and it's reciprocal by the $(t)$ test.

Potence ratio, i.e., the relative potency of gene set $(P)$ was used to determine the direction of dominance according to the following formula (Smith, 1952):

$$
P=\frac{\overline{F_{1}}-M P}{\left.1 / 2 \overline{\left(P_{2}\right.}-\overline{P_{1}}\right)}
$$

Where: $\overline{F_{1}}=$ First generation mean, $\overline{P_{1}}=$ Mean of the lower parent, $\overline{P_{2}}=$ Mean of the higher parent, and $M P=$ Mid parent value $\left.=1 / 2 \overline{\left(P_{1}\right.}+\overline{P_{2}}\right)$. The absence of dominance was assumed when the difference between the parents was significant and $F_{1}$ - MP was not significant. Complete dominance was assumed when potence ratio equaled to or did not significantly differ from \pm 1.0 . Meanwhile, partial dominance was considered when potence ratio was between +1.0 and -1.0 , but was not equal to zero. Over dominance (Heterosis) was assumed when potence ratio exceeded \pm 1.0 .

Heterosis was calculated on better parent basis using the following formula:

$$
\text { Better-parent heterosis }=\frac{\overline{\mathrm{F}_{1}-\overline{\mathrm{BP}}}}{\overline{\mathrm{BP}}} \times 100 \quad \text { (Sinha and Khanna, 1975) }
$$

Where: $\overline{F_{1}}=$ Mean of the first hybrid generation, and $\overline{\mathrm{BP}}=$ Mean of the better parent.

The minimum number of genes controlling the character in each cross was calculated using Wright formula as follows: 


$$
N=\frac{0.25\left(0.75-h+h^{2}\right) D^{2}}{V_{F 2}-V_{F 1}} \quad \text { (Burton, 1951) }
$$

where:

$$
h=\frac{F_{1}-P_{1}}{\overline{P_{2}}-\overline{P_{1}}}
$$

$\mathrm{N}=$ The minimum number of genes controlling the character in each cross, $\mathrm{D}=$ The difference between the observed mean of female and male parents, $\bar{P}_{1}, \bar{P}_{2}$ and $F_{1}$ are means of the parents and $F_{1}$ populations, respectively, and $V_{F 1}$ and $V_{F 2}=$ Variances of the $\overline{F_{1}}$ and $F_{2}$ populations, respectively.

Broad senses heritability was calculated using the equation:

$$
\mathrm{BSH}=\frac{\mathrm{V}_{\mathrm{G}}}{\mathrm{V}_{\mathrm{P}}} \times 100 \quad \text { (Allard, 1960) }
$$

where: $V_{G}=$ Genetic variance which was calculated by subtracting the environmental variance $\left(V_{E}\right)$ from $\left(V_{P}\right), V_{P}=$ Phenotypic variance $=V_{F 2}$, and $V_{E}=$ Environmental variance which was calculated as the geometric mean of variances of the nonsegregating populations, i.e. parents and $\mathrm{F}_{1}$.

\section{RESULTS AND DISCUSSION}

\section{Number of days to flowering}

Data recorded on number of days to flowering of parental, $F_{1}, F_{1} r$ and $F_{2}$ populations of the crosses Master $\times$ Perfection 57, Master $\times$ Prism and Master $\times$ Twin are presented in Table 2.

Parents were highly significantly different in this trait. $F_{1}$ and $F_{2}$ means were intermediate between their respective parents in all studied crosses with tendency towards the later parent. $F_{2}$ plants were widely distributed between their parents with transgressive segregations over the earlier parent in all three crosses. 
Table 2. Distribution, mean and variance of number of days to flowering for the parental, $F_{1}, F_{1} r$ and $F_{2}$ populations of some garden pea crosses.

\begin{tabular}{|c|c|c|c|c|c|c|c|c|c|c|c|c|c|c|}
\hline \multirow[b]{2}{*}{ Population } & \multicolumn{10}{|c|}{ Frequency of number of days to flowering in class ${ }^{2}$} & \multirow{2}{*}{$\begin{array}{l}\text { Total No. } \\
\text { of plants }\end{array}$} & \multicolumn{2}{|l|}{ Mean } & \multirow{2}{*}{$\begin{array}{c}\text { Variance } \\
\qquad\left(\delta^{2}\right)\end{array}$} \\
\hline & 41 & 44 & 47 & 50 & 53 & 56 & 59 & 62 & 65 & 68 & & $X \pm S_{x}$ & $y$ & \\
\hline & \multicolumn{10}{|c|}{ Master $\times$ Perfection 57} & & & & \\
\hline Master $\left(P_{1}\right)$ & & 27 & 3 & & & & & & & & 30 & $44.30 \pm 0.17$ & $* *$ & 0.838 \\
\hline Perfection $57\left(\mathrm{P}_{2}\right)$ & & & & & 7 & 11 & 8 & 4 & & & 30 & $56.90 \pm 0.54\}$ & & 8.783 \\
\hline$F_{1}$ & & & & & 12 & 14 & 2 & 2 & & & 30 & $55.40 \pm 0.46$ & NS & 6.455 \\
\hline$F_{1} r$ & & & & 2 & 9 & 13 & 1 & 5 & & & 30 & $55.80 \pm 0.63\}$ & & 11.752 \\
\hline $\mathrm{F}_{2}$ & 2 & 15 & 14 & 23 & 29 & 18 & 18 & 18 & 22 & 23 & 182 & $56.41 \pm 0.57$ & & 59.150 \\
\hline \multicolumn{15}{|c|}{ Master $\times$ Prism } \\
\hline Master $\left(P_{1}\right)$ & & 27 & 3 & & & & & & & & 30 & $44.30 \pm 0.17$ & $* *$ & 0.838 \\
\hline Prism $\left(P_{2}\right)$ & & & & & & 10 & 6 & 14 & & & 30 & $59.40 \pm 0.49\}$ & & 7.283 \\
\hline $\mathrm{F}_{1}$ & & & 3 & 5 & 18 & 4 & & & & & 30 & $52.30 \pm 0.45$ & NS & 6.010 \\
\hline$F_{1} r$ & & & 1 & 10 & 12 & 5 & 2 & & & & 30 & $52.70 \pm 0.53$ & & 8.286 \\
\hline $\mathrm{F}_{2}$ & 5 & 9 & 16 & 9 & 14 & 7 & 15 & 40 & 23 & 21 & 159 & $58.02 \pm 0.63$ & & 63.171 \\
\hline \multicolumn{15}{|c|}{ Master $\times$ Twin } \\
\hline Master $\left(\mathrm{P}_{1}\right)$ & & 27 & 3 & & & & & & & & 30 & $44.30 \pm 0.17$ & $* *$ & 0.838 \\
\hline Twin $\left(P_{2}\right)$ & & & & & 4 & 7 & 11 & 4 & 4 & & 30 & $58.70 \pm 0.65$ & & 12.810 \\
\hline$F_{1}$ & & & & & 8 & 14 & 6 & 2 & & & 30 & $56.20 \pm 0.48\}$ & NS & 6.786 \\
\hline$F_{1} r$ & & & & & 6 & 15 & 4 & 5 & & & 30 & $56.80 \pm 0.54$ & & 8.648 \\
\hline $\mathrm{F}_{2}$ & 8 & 18 & 15 & 10 & 14 & 11 & 26 & 22 & 17 & 7 & 148 & $55.15 \pm 0.66$ & & 63.923 \\
\hline
\end{tabular}

${ }^{z}$ Each class represents a range of 3 days and class values indicated represent class centers.

${ }^{y}$ Pairs of means were either highly significantly $(* *)$, significantly $(*)$, or not significantly (NS) different from each other according to $(t)$ test. 
No significant differences were observed between $F_{1}$ and it's reciprocal for number of days to flowering trait in the all crosses indicating absence of maternal effect for this character. These results partially agree with the finding of Noser (2002) and Hamed (2005) on peas, they found that maternal effect was existed only in one cross.

Quantitative genetic parameters obtained for number of days to flowering are shown in Table 3.

Positive $P$ values (potence ratio) were estimated indicating partial dominance of the late parent in all crosses. These results typically confirm previous reports of Hamed (2005) and Abbas (2012), they observed partial dominance towards the late parent in the all studied crosses. Meanwhile, different types of dominance were obtained by Noser (2002) and Sood and Kalia (2006).

Positive heterosis - based on early parent - was estimated as $26.86 \%, 25.06 \%$, and $18.06 \%$ for the crosses, i.e., Master $\times$ Twin, Master $\times$ Perfection 57 and Master $\times$ Prism, respectively. These results agree with the findings of Hamed (2005) who found positive heterosis based on early parent in the all studied crosses, meanwhile, Noser (2002) on peas found negative heterosis in some crosses and positive heterosis values in the others.

Minimum number of genes controlling number of days to flowering trait was estimated as one pair of genes in the all studied crosses as estimated by Write formula. These results are in agreement with that of Rajaneesh and Ram (2001) on peas they found that this trait was governed by a single major gene.

Estimates of BSH for number of days to flowering trait (Table 3) were high and ranged from $93.47 \%$ to $94.74 \%$. These results partially agree with the previous results of Bora et al. (2009), Kumari et al. (2009) and Galal (2014) on peas. 
Table 3. Quantitative genetic parameters obtained for some characters in some garden pea crosses.

\begin{tabular}{|c|c|c|c|c|}
\hline Parameter & $\begin{array}{c}\text { Potence ratio } \\
\text { (P) }\end{array}$ & $\begin{array}{l}\text { Better-parent } \\
\text { heterosis (\%) }\end{array}$ & $\begin{array}{c}\text { Minimum } \\
\text { number of genes } \\
\text { (MNG) }\end{array}$ & $\begin{array}{c}\text { Broad sense } \\
\text { heritability } \\
\text { (BSH\%) }\end{array}$ \\
\hline & \multicolumn{4}{|c|}{ Number of days to flowering } \\
\hline Master $\times$ Perfection 57 & 0.76 & 25.06 & 0.49 & 93.88 \\
\hline Master $\times$ Prism & 0.06 & 18.06 & 0.50 & 94.74 \\
\hline Master $\times$ Twin & 0.65 & 26.86 & 0.55 & 93.47 \\
\hline & \multicolumn{4}{|c|}{ Pod length } \\
\hline Master $\times$ Perfection 57 & -0.16 & -12.43 & 2.39 & 48.51 \\
\hline Master $\times$ Prism & 0.31 & -9.07 & 2.23 & 66.38 \\
\hline Master $\times$ Twin & 0.31 & -7.73 & 17.59 & 31.47 \\
\hline & \multicolumn{4}{|c|}{ Number of seeds/pod } \\
\hline Master $\times$ Perfection 57 & 0.00 & -7.86 & 0.56 & 29.22 \\
\hline Master $\times$ Prism & 2.40 & 7.33 & 0.03 & 59.78 \\
\hline & \multicolumn{4}{|c|}{ Seed weight } \\
\hline Master $\times$ Perfection 57 & -0.30 & -13.08 & 2.16 & 28.73 \\
\hline Master $\times$ Prism & -0.65 & -22.88 & 0.75 & 23.88 \\
\hline Master $\times$ Twin & 0.27 & -14.72 & 5.38 & 42.23 \\
\hline & \multicolumn{4}{|c|}{ Shelling percentage } \\
\hline Master $\times$ Perfection 57 & 3.71 & 12.21 & 0.13 & 41.41 \\
\hline Master $\times$ Prism & 0.66 & -2.16 & 0.23 & 58.42 \\
\hline
\end{tabular}

\section{Pod length}

Data obtained on pod length trait of parental, $F_{1}, F_{1} r$ and $F_{2}$ populations of the crosses, i.e., Master $\times$ Perfection 57, Master $\times$ Prism and Master $\times$ Twin are presented in Table 4. 
Table 4. Distribution, mean and variance on pod length $(\mathrm{cm})$ for the parental, $F_{1}, F_{1} r$ and $F_{2}$ populations of some garden pea crosses.

\begin{tabular}{|c|c|c|c|c|c|c|c|c|c|c|c|}
\hline \multirow{2}{*}{ Population } & \multicolumn{8}{|c|}{ Frequency of pod length $(\mathrm{cm})$ in class ${ }^{2}$} & \multirow{2}{*}{$\begin{array}{l}\text { Total No. } \\
\text { of plants }\end{array}$} & \multirow[b]{2}{*}{$x \pm S_{x}$} & \multirow{2}{*}{$\begin{array}{c}\text { Variance } \\
\left(\delta^{2}\right)\end{array}$} \\
\hline & 5.6 & 6.7 & 7.8 & 8.9 & 10.0 & 11.1 & 12.2 & 13.3 & & & \\
\hline & \multicolumn{8}{|c|}{ Master $\times$ Perfection 57} & & \multirow{3}{*}{$\left.\begin{array}{r}10.92 \pm 0.15 \\
8.57 \pm 0.21\end{array}\right\}^{* *}$} & \multirow[b]{2}{*}{0.675} \\
\hline Master $\left(\mathrm{P}_{1}\right)$ & & & & 1 & 8 & 16 & 5 & & 30 & & \\
\hline Perfection $57\left(\mathrm{P}_{2}\right)$ & & 3 & 10 & 12 & 3 & 2 & & & 30 & & 1.264 \\
\hline $\mathrm{F}_{1}$ & & & 2 & 9 & 18 & 1 & & & 30 & $9.56 \pm 0.14, N S$ & 0.551 \\
\hline$F_{1} r$ & & 1 & 2 & 15 & 7 & 5 & & & 30 & $9.38 \pm 0.20$ & 1.142 \\
\hline \multirow{2}{*}{$\mathrm{F}_{2}$} & 1 & 14 & 45 & 70 & 39 & 8 & 5 & & 182 & $8.86 \pm 0.09$ & 1.510 \\
\hline & \multicolumn{8}{|c|}{ Master $\times$ Prism } & & \multirow{5}{*}{$\left.\begin{array}{r}10.92 \pm 0.15 \\
8.06 \pm 0.13\end{array}\right\}^{* *}$} & \\
\hline Master $\left(\mathrm{P}_{1}\right)$ & & & & 1 & 8 & 16 & 5 & & 30 & & 0.675 \\
\hline Prism $\left(P_{2}\right)$ & & 3 & 17 & 10 & & & & & 30 & & 0.474 \\
\hline $\mathrm{F}_{1}$ & & & & 8 & 16 & 6 & & & 30 & & 0.579 \\
\hline$F_{1} r$ & & & & 12 & 9 & 6 & 3 & & 30 & & 1.252 \\
\hline \multirow[t]{2}{*}{$\underline{F}_{2}$} & 2 & 3 & 17 & 46 & 56 & 28 & 5 & 2 & 159 & $9.63 \pm 0.10$ & 1.695 \\
\hline & \multicolumn{8}{|c|}{ Master $\times$ Twin } & & \multirow{3}{*}{$\left.\begin{array}{r}10.92 \pm 0.15 \\
8.46 \pm 0.12\end{array}\right\}^{* *}$} & \\
\hline Master $\left(P_{1}\right)$ & & & & 1 & 8 & 16 & 5 & & 30 & & 0.675 \\
\hline Twin $\left(P_{2}\right)$ & & 1 & 11 & 17 & 1 & & & & 30 & & 0.467 \\
\hline $\mathrm{F}_{1}$ & & & & 8 & 13 & 8 & 1 & & 30 & $10.07 \pm 0.17$ jS & 0.829 \\
\hline$F_{1} r$ & & & 2 & 8 & 13 & 7 & & & 30 & $9.82 \pm 0.18$ & 0.925 \\
\hline$F_{2}$ & & 1 & 2 & 34 & 66 & 39 & 6 & & 148 & $10.07 \pm 0.08$ & 0.933 \\
\hline
\end{tabular}

${ }^{z}$ Each class represents a range of $1.1 \mathrm{~cm}$ and class values indicated represent class centers.

${ }^{y}$ Pairs of means were either highly significantly $(* *)$, significantly $(*)$, or not significantly (NS) different from each other according to (t) test. 
In the all crosses, parents were distinctively different in pod length trait. $F_{1}$ and $F_{2}$ means were intermediate between their respective parents with transgressive segregations of $F_{2}$ over the highest parent in the cross Master $\times$ Prism.

Non-significant differences were observed between $F_{1}{ }^{\prime}$ and their reciprocals for pod length in all studied crosses indicating no maternal effect. These results typically agree with those of Hamed (2005) who detected absence of maternal effect for this character in the all studied crosses.

Quantitative genetic parameters obtained for pod length trait are presented in Table 3.

Different types of dominance were observed for pod length character. Positive $\mathrm{P}$ values (potence\%) were estimated indicating partial dominance towards the high parent in the crosses, i.e., Master $\times$ Prism and Master $\times$ Twin, meanwhile, negative $P$ value was observed indicating partial dominance towards the short pod in the cross Master $\times$ Perfection 57 . These results partially agree with the results obtained by Hamed (2005) who found complete and partial dominance towards the highest parent for this character.

Negative heterosis values ranged from $-12.43 \%$ to $-7.73 \%$ were obtained for the all three studied crosses. These results agree with the results obtained by Hamed (2005) who found extremely low positive heterosis (1.6\%) for pod length in one pea cross, meanwhile, negative heterosis values were obtained for the other studied crosses for this trait and ranged from $-11.7 \%$ to $-1.9 \%$.

Minimum number of genes which controlling pod length as shown in Table 3 was estimated as three pairs in the crosses Master $\times$ Perfection 57, Master $\times$ Prism and eighteen pairs of genes in the cross Master $\times$ Twin. These results partially agree with the previous results which obtained that MNG conditioning pod length were estimated as 1-3 pairs of genes (Hamed, 2005).

Estimates of broad sense heritability (BSH) for pod length ranged from $31.47 \%$ to $66.38 \%$ indicating high to moderate environmental effect on this trait. These results agree with the results obtained by Hamed (2005) who estimated it as $44.4 \%$ to $64.8 \%$. Also, Chaudhary and Sharma (2003) and Gupta et al. (2006) estimated it as $35 \%$ and $42.25 \%$, respectively. Meanwhile, disagree with Sharma et al. (2003) and 
El-Dakkak et al. (2014) they found high estimates of heritability in broad sense for this trait.

\section{Number of seeds/pod}

Data obtained on number of seeds/pod trait of parental, $F_{1}, F_{1} r$ and $F_{2}$ populations of the crosses Master $\times$ Perfection 57 and Master $\times$ Prism are presented in Table 5.

In the two crosses, parents were distinctively different in number of seeds/ pod. In the cross Master $\times$ Perfection 57 , mean of $F_{1}$ was intermediate between their respective parents, meanwhile, $F_{2}$ mean was lower than the low parent. However, in the cross Master $\times$ Prism, $F_{1}$ mean was higher than the high parent, meanwhile, mean of $F_{2}$ was intermediate between their parents and very close to that of the low parent. $F_{2}$ plants of each cross were widely distributed between its two parents.

No significant differences were obtained between $\mathrm{F}_{1}$ 's and their reciprocals for this trait in the two studied crosses indicating absence of maternal effect. These results typically agree with those of Hamed (2005) who reported that maternal effect was not observed in any one of the studied crosses. This could be due to nature of self pollination in pea.

Quantitative genetic parameters obtained for number of seeds/pod are presented in Table 3.

Positive $\mathrm{P}$ values indicating complete dominance towards high parent which was found in the cross Master $\times$ Prism, however, in the cross Master $\times$ Perfection 57 was absence. These results agree with the results of Noser (2002) who found different types of dominance for this trait in peas.

Data obtained on heterosis (Table 3) indicated that the cross Master $\times$ Prism exhibited low positive heterosis value estimated as $7.33 \%$, however, the cross Master $\times$ Perfection 57 exhibited negative heterosis $(-7.86 \%)$. These results agree with the results of Noser (2002) who found positive heterosis over the better parent in three crosses, meanwhile, three other crosses exhibited negative heterosis for number of seeds/pod trait. 
Table 5. Distribution, mean and variance of number of seeds/pod for the parental, $F_{1}, F_{1} r$ and $F_{2}$ populations of some garden pea crosses.

\begin{tabular}{|c|c|c|c|c|c|c|c|c|c|c|c|c|c|}
\hline \multirow{2}{*}{ Population } & \multicolumn{9}{|c|}{ Frequency of number of seeds/pod in class ${ }^{2}$} & \multirow{2}{*}{$\begin{array}{l}\text { Total No. } \\
\text { of plants }\end{array}$} & \multicolumn{2}{|l|}{ Mean } & \multirow{2}{*}{$\begin{array}{c}\text { Variance } \\
\left(\delta^{2}\right)\end{array}$} \\
\hline & 1.6 & 2.9 & 4.2 & 5.5 & 6.8 & 8.1 & 9.4 & 10.7 & 12.0 & & $X \pm S_{x}$ & & \\
\hline \multicolumn{14}{|c|}{ Master $\times$ Perfection 57} \\
\hline Master $\left(P_{1}\right)$ & & & 1 & 2 & 6 & 5 & 15 & 1 & & 30 & $8.27 \pm 0.28$ & $* *$ & 2.417 \\
\hline Perfection $57\left(P_{2}\right)$ & & & 4 & 5 & 7 & 11 & 3 & & & 30 & $6.97 \pm 0.29$ & & 2.533 \\
\hline$F_{1}$ & & & & 4 & 11 & 10 & 3 & 1 & 1 & 30 & $7.62 \pm 0.28$ & NS & 2.269 \\
\hline$F_{1} r$ & & & & 10 & 3 & 4 & 11 & 2 & & 30 & $7.75 \pm 0.34$ & & 3.489 \\
\hline $\mathrm{F}_{2}$ & 3 & 12 & 27 & 68 & 29 & 25 & 18 & & & 182 & $6.02 \pm 0.14$ & & 3.396 \\
\hline \multicolumn{14}{|c|}{ Master $\times$ Prism } \\
\hline Master $\left(P_{1}\right)$ & & & 1 & 2 & 6 & 5 & 15 & 1 & & 30 & $8.27 \pm 0.28$ & $* *$ & 2.417 \\
\hline Prism $\left(P_{2}\right)$ & & & & 7 & 7 & 11 & 5 & & & 30 & $7.41 \pm 0.25$ & & 1.834 \\
\hline$F_{1}$ & & & & 1 & 3 & 4 & 21 & 1 & & 30 & $8.88 \pm 0.20$ & NS & 1.235 \\
\hline$F_{1} r$ & & & & 5 & 3 & 6 & 12 & 3 & 1 & 30 & $8.45 \pm 0.32$ & & 3.139 \\
\hline $\mathrm{F}_{2}$ & 4 & 1 & 12 & 31 & 25 & 28 & 51 & 7 & & 159 & $7.43 \pm 0.17$ & & 4.382 \\
\hline
\end{tabular}

z Each class represents a range of 1.3 seeds and class values indicated represent class centers.

${ }^{y}$ Pairs of means were either highly significantly $(* *)$, significantly $(*)$, or not significantly (NS) different from each other according to (t) test. 
Minimum number of genes controlling number of seeds/pod trait was estimated as one pair in the two studied crosses. These results typically agree with those obtained by Hamed (2005) who estimated it as a single pair of genes.

Broad sense heritability estimated for number of seeds/pod was low to moderate and estimated as $29.22 \%$ and $59.78 \%$ in the crosses Master $\times$ Perfection 57 and Master $\times$ Prism, respectively. These results agree with that obtained by Noser (2002) who found that BSH for this trait ranged from $14.67 \%$ to $43.47 \%$ but disagree with the finding of Galal (2014) who estimated high values of heritability in the broad sense for this trait. Meanwhile, Chaudhary and Sharma (2003), Hamed (2005), Gupta et al. (2006) and El-Dakkak et al. (2014) on peas indicated that it was moderate. These different results could be due to using different genotypes or different environmental conditions.

\section{Seed weight}

Data obtained on seed weight of parental, $F_{1}, F_{1} r$ and $F_{2}$ populations of the crosses Master $\times$ Perfection 57, Master $\times$ Prism and Master $\times$ Twin are presented in Table 6.

In the all crosses, parents were distinctively different in seed weight. $F_{1}$ and $F_{2}$ means were intermediate between their respective parents except in the cross Master $\times$ Perfection 57 where its $F_{2}$ mean was lower than the low parent.

No significant differences were observed between $\mathrm{F}_{1}$ 's and their reciprocals for this character in the all crosses indicating no maternal effect. These results agree with those of Noser (2002) and Hamed (2005).

Quantitative genetic parameters obtained for seed weight trait are presented in Table 3.

Different types of dominance were observed for seed weight character. Positive $P$ value was estimated indicating complete dominance towards the heaviest parent seed in the cross Master $\times$ Twin, meanwhile, negative $P$ values were observed indicating complete dominance towards the lowest parent in the crosses Master $\times$ Perfection 57 and Master $\times$ Prism. These results agree with the results of Noser (2002) who revealed that complete dominance of the highest parent was found in two crosses, complete dominance of the lowest parent was observed in three crosses and partial dominance of the lowest parent was detected in one cross. In the same direction, Hamed (2005) found partial dominance of the highest parent in some crosses and partial dominance of the lowest parent in others. 
Table 6. Distribution, mean and variance of seed weight $(\mathrm{g})$ for the parental, $F_{1}, F_{1} r$ and $F_{2}$ populations of some garden pea crosses.

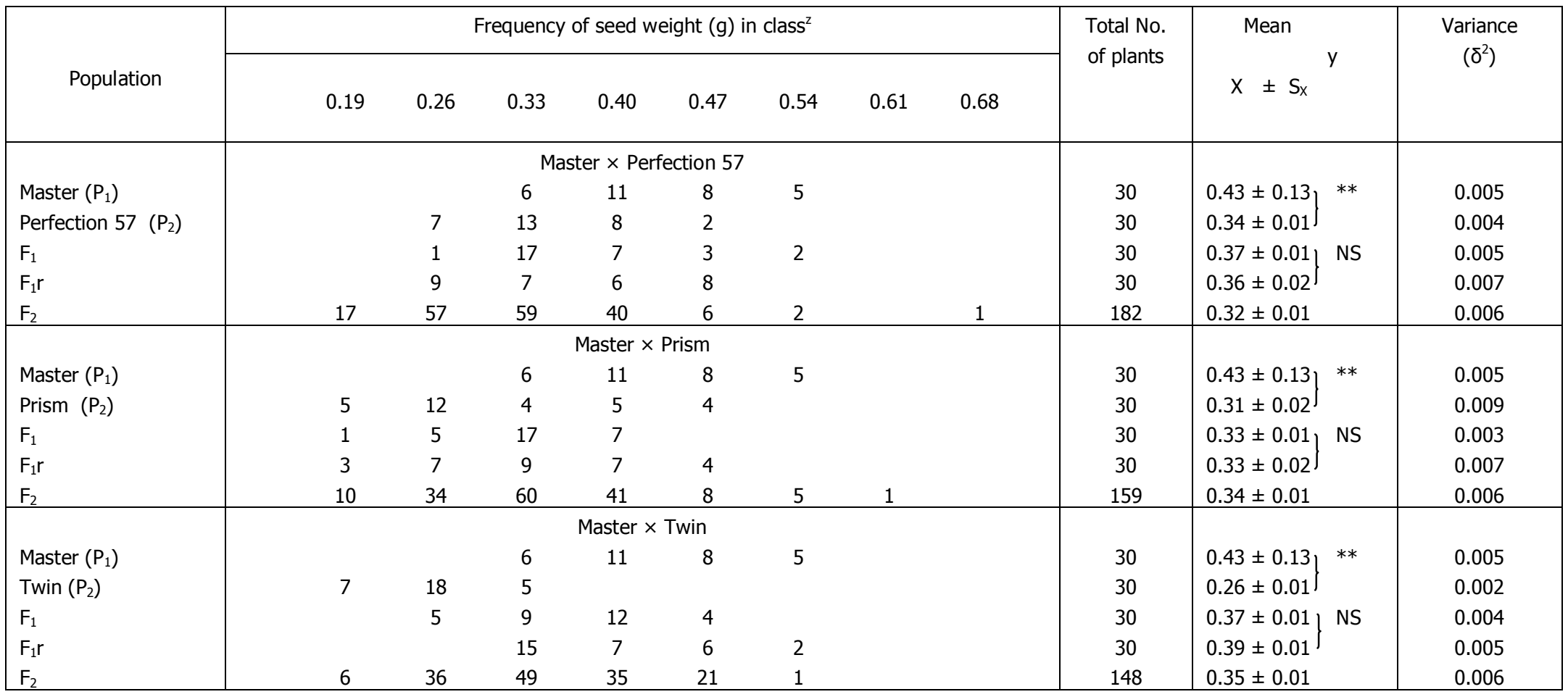

${ }^{\mathrm{z}}$ Each class represents a range of $0.07 \mathrm{~g}$ and class values indicated represent class centers.

${ }^{y}$ Pairs of means were either highly significantly $\left({ }^{* *}\right)$, significantly $(*)$, or not significantly (NS) different from each other according to (t) test. 
Negative heterosis values for this trait were estimated for the all studied crosses ranged from $-22.88 \%$ to $-13.08 \%$. These results agree with the results shown by Hamed (2005) who found negative high-parent heterosis values in the all studied crosses ranged from $-17.5 \%$ to $-10.3 \%$. Meanwhile, Noser (2002) found positive heterosis, based on the highest parent, estimated as $9.1 \%$ and $3.5 \%$ in two crosses and found negative heterosis values ranged from $-21.1 \%$ to $-12.1 \%$ in four other crosses.

Minimum number of genes controlling seed weight was differed according to different crosses and estimated as one pair in the cross Master $\times$ Prism, three pairs of genes in the cross Master $\times$ Perfection 57 and six pairs in the cross Master $\times$ Twin. These results were partially in agreement with the results of Hamed (2005) and Noser (2002) who estimated number of genes controlling seed weight character as 1-2 pairs.

Estimates of BSH were low and ranged from $23.88 \%$ to $42.23 \%$. These results confirm the interaction between environmental conditions and genetic constituents. These results partially agree with that estimated by Noser (2002), Hamed (2005) and El-Dakkak et al. (2014) they estimated it as $18.18 \%$ to $94.29 \%$, from $11.9 \%$ to $24.5 \%$ and from $47.10 \%$ to $99.21 \%$, respectively. On the other hand, Chaudhary and Sharma (2003) and Singh et al. (2011) indicated that it was high.

\section{Shelling percentage:}

Data recorded on shelling percentage of the parental, $F_{1}, F_{1} r$ and $F_{2}$ populations of the crosses Master $\times$ Perfection 57 and Master $\times$ Prism are presented in Table 7.

The parents were distinctively different in shelling percentage in the two studied crosses. $F_{1}$ and $F_{2}$ means were intermediate between their respective parents in the cross Master $\times$ Prism and very close to that of the low parent, meanwhile, in the cross Master $\times$ Perfection 57 , the mean of $F_{1}$ was higher than the high parent and $F_{2}$ gave the same value of the low parent. $F_{2}$ plants of each cross were widely distributed between their parents with transgressive segregations over the high parents. 
Table 7. Distribution, mean and variance of shelling percentage (\%) for the parental, $F_{1}, F_{1} r$ and $F_{2}$ populations of some garden pea crosses.

\begin{tabular}{|c|c|c|c|c|c|c|c|c|c|c|c|}
\hline \multirow{2}{*}{ Population } & \multicolumn{8}{|c|}{ Frequency of shelling percentage (\%) in class ${ }^{2}$} & \multirow{2}{*}{$\begin{array}{l}\text { Total No. } \\
\text { of plants }\end{array}$} & \multirow[t]{2}{*}{ Mean } & \multirow{2}{*}{$\begin{array}{c}\text { Variance } \\
\qquad\left(\delta^{2}\right)\end{array}$} \\
\hline & 32.5 & 37.6 & 42.7 & 47.8 & 52.9 & 58.0 & 63.1 & 68.2 & & & \\
\hline & \multicolumn{8}{|c|}{ Master $\times$ Perfection 57} & & & \\
\hline Master $\left(P_{1}\right)$ & & 2 & 5 & 12 & 11 & & & & 30 & $48.14 \pm 0.84, * *$ & 21.406 \\
\hline Perfection $57\left(P_{2}\right)$ & & & 5 & 5 & 5 & 15 & & & 30 & $52.90 \pm 1.09$ & 35.876 \\
\hline$F_{1}$ & & & & 2 & 4 & 14 & 4 & 6 & 30 & $59.36 \pm 1.06, \mathrm{NS}$ & 33.963 \\
\hline$F_{1} r$ & & & 1 & 1 & 3 & 7 & 11 & 7 & 30 & $60.89 \pm 1.16$ & 40.689 \\
\hline \multirow[t]{2}{*}{$\mathrm{F}_{2}$} & 18 & 19 & 30 & 45 & 33 & 19 & 9 & 9 & 182 & $48.14 \pm 0.69$ & 86.395 \\
\hline & \multicolumn{8}{|c|}{ Master $\times$ Prism } & & & \\
\hline Master $\left(P_{1}\right)$ & & 2 & 5 & 12 & 11 & & & & 30 & $48.14 \pm 0.84, * *$ & 21.406 \\
\hline Prism $\left(P_{2}\right)$ & & & 3 & 8 & 2 & 7 & 10 & & 30 & $55.11 \pm 1.35$ & 55.040 \\
\hline$F_{1}$ & & & & 8 & 10 & 10 & 2 & & 30 & $53.92 \pm 0.86$ & 22.243 \\
\hline$F_{1} r$ & & & 4 & 3 & 7 & 6 & 5 & 5 & 30 & $56.30 \pm 1.51$ & 68.762 \\
\hline$F_{2}$ & 7 & 23 & 24 & 48 & 31 & 13 & 5 & 8 & 159 & $48.22 \pm 0.67$ & 71.435 \\
\hline
\end{tabular}

${ }^{z}$ Each class represents a range of $5.1 \%$ and class values indicated represent class centers.

${ }^{y}$ Pairs of means were either highly significantly $\left({ }^{* *}\right)$, significantly $\left(^{*}\right)$, or not significantly (NS) different from each other according to (t) test. 
Non-significant differences were observed between $F_{1}$ 's and their reciprocals for this character in the two crosses indicating no maternal effect. These results typically agree with results obtained by Noser (2002) and Hamed (2005).

Quantitative genetic parameters obtained for shelling percentage are presented in Table 3.

Positive $\mathrm{P}$ values were estimated indicated over dominance and complete dominance of the high parent in the crosses Master $\times$ Perfection 57 and Master $\times$ Prism, respectively. These results typically agree with the results obtained by Hamed (2005) who found that over dominance and complete dominance of the best parent were obtained. Also, Noser (2002) found complete dominance of the high parent in the all studied crosses. While, Sood and Kalia (2006) and Abbas (2012) found that shelling percentage was controlled by over dominance.

Positive high-parent heterosis value (12.21\%) was estimated in the cross Master $\times$ Perfection 57. However, very low negative heterosis was estimated as $2.16 \%$ in the cross Master $\times$ Prism. These results typically agree with previous results obtained by Noser (2002) who estimated low positive heterosis, based on the highest parent for shelling percentage trait in two crosses, while four other crosses gave negative heterosis. Also, Hamed (2005) indicated that three out of the 4 studied crosses exhibited positive high-parent heterosis for shelling percentage, meanwhile, one hybrid exhibited very low negative heterosis.

Results in Table 3 showed that minimum number of genes controlling shelling percentage character was estimated as a single pair in the two studied crosses. These results typically agree with results obtained by Noser (2002). Also, Hamed (2005) and Abbas (2012) estimated it as 1 to 3 pairs of genes.

Estimates of BSH for shelling percentage character (Table 3) estimated as $41.41 \%$ and $58.42 \%$ in the crosses Master $\times$ Perfection 57 and Master $\times$ Prism, respectively, indicating moderate environmental effect on this trait. These results agree with those obtained by Gupta et al. (2006), Kumari et al. (2009), and Sharma et al. (2011) who found that BSH was moderate. Meanwhile, Noser (2002) and Hamed (2005) found that it was low to moderate. However, Chaudhary and Sharma (2003) estimated it as $97 \%$.

\section{CONCLUSION}

It's clear from the previous results that there are some traits, viz, number of days to flowering and shelling percentage are controlled by one gene and had moderate to high heritability, so the selection for these traits is preferred in the early generations. On the other hand, pod length, and seed weight traits had polygenic 
effect and low to moderate heritability, so the selection for these traits is suggested to be done in the late generations.

\section{REFERENCES}

1. Abbas, H. S. 2012. Inheritance of earliness, dry matter and shelling in pea. Res. J. Agric. Bio. Sci. 8 (1): 1-5. http://www.aensionline.com

2. Allard, W. R. 1960. Principles of Plant Breeding. John Wiley \& Sons, Inc. 473 p.

3. Bora, L., V. K. Sharma, H. C. Raturi and S. K. Maurya. 2009. Studies on hybrid breeding and genetic variability in vegetable pea under high hilly condition of Uttarakhand. Annals of Horticulture 2 (2): 171-176.

4. Burton, G. W. 1951. Quantitative inheritance in pearl millet, Pennisetum glaucum. Agron. J. 43: 409-417.

5. Choudhary, D. K. and R. R. Sharma. 2003. Genetic variability, correlation and path analysis for pod yield and its components in garden pea. Indian J. Hort. 60 (3): 251-256.

6. El-Dakkak, A. A. A., G. A. Zayed and M. A. H. Abd El-Hady. 2014. Improving productivity and earliness for pea by selection under sohag conditions. Egypt. J. Appl. Sci., 29 (11): 523-533.

7. Galal, R. M. 2014. Genetic analysis of pea yield and its components by diallel crossing. Egypt. J. Plant Breed. 18 (4): 799-811.

8. Gupta, A. J., Y. V. Singh and T. S. Verma. 2006. Genetic variability and heritability in garden pea (Pisum sativum L.). Indian J. Hort. 63 (3): 332-334.

9. Hamed, A. A. 2005. Genetic Studies on Powdery Mildew Resistance and Some Economic Characters in Some Pea Cultivars. Ph. D. Thesis, Fac. Agric., Cairo Univ., Egypt, 97 p.

10. Kosev, V., I. Pachev, S. Angelova and A. Mikic. 2012. Inheritance of quantitative traits in crosses between two Pisum sativum subspecies with particular reference to their breeding value. Russian J. Genet. 48 (1): 41-46. http://www. springerlink.com

11. Kumari, N., J. P. Srivastava and B. Singh. 2009. Heritability and genetic advance in vegetable pea (Pisum sativum L.). Annals of Hort. 2 (2): 224-225.

12. Noser, M. A 2002. Genetic Study on Some Economic Characters of Peas. Ph. D. Thesis, Fac. Agric., Cairo Univ., Egypt, 78 p.

13. Rajaneesh, S. and H. Ram. 2001. Inheritance of days to flowering and rust resistance in peas. Research on Crops 2 (3): 414-418. (c.a. Plant Breed. Abstr. 72:6867, 2002). 
14. Ravinder, K., M. Singh, S. Kaur, P. S. Brar and T. S. Dhillon. 2003. Heterosis and correlation studies in pea (Pisum sativum L.). Environment and Ecology 21 (1): 11-15. (c.a. Plant Breed. Abstr. 73: 6278, 2003).

15. Sharma, M. K., A. Chandel and U. K. Kohli. 2011. Genetic evaluation, correlation coefficients and path analysis in garden pea (Pisum sativum Var. Hortense L.). Prog. Agric. 11 (2): 434-439.

16. Singh, A., S. Singh and J. D. P. Babu. 2011. Heritability, character association and path analysis studies in early segregating population of field pea (Pisum sativum L. var. arvense). Inter. J. Plant Breed. Genet. 5 (1): 86-92. http://scialert.net

17. Sinha, S. K. and R. Khanna. 1975. Physiological, biochemical and genetic basis of heterosis. Adv. Agron. 27: 123-174.

18. Smith, H. H. 1952. Fixing Transgressive Vigur in Nicotiana rustica. Iowa State College Press, Ames. Iowa. p. 161-174.

19. Sood, M. and P. Kalia. 2006. Gene action of yield-related traits in garden pea (Pisum sativum Linn.). SABRAO J. Breed. Genet. 38 (1): 1-17. http://www. indianjournal.com 


\section{دراسات ور اثيه على بعض الصفات الكمية فى البسلة r - ور اثة عدد الأيام حتى التزهير وبعض مواصفات القرن}

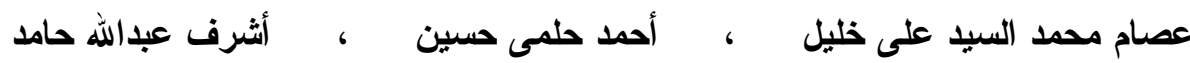

$$
\text { أقسام بحوث الخضر - معهد بحوث البساتين - مركز البحوث الزراعية }
$$

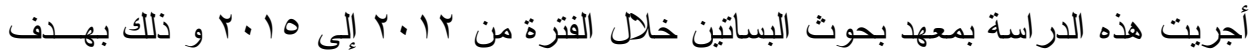
در اسة ور اثة بعض الصفات الاقتصادية في البسلة الخضر اء منل عدد الأيام حتى التز هير ، وطـــــل

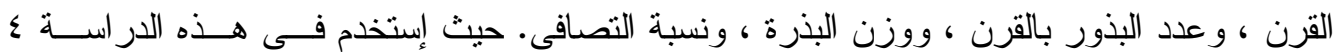

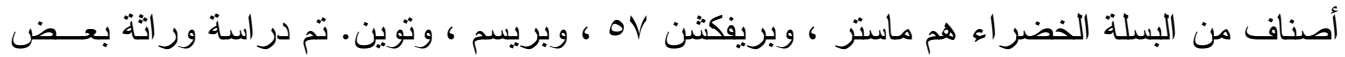

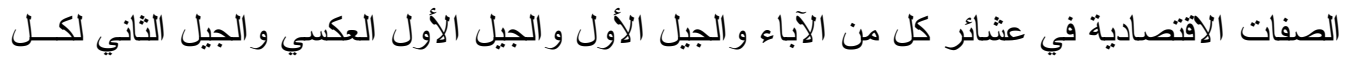

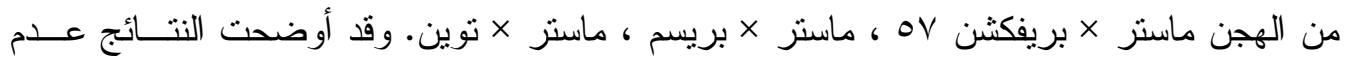

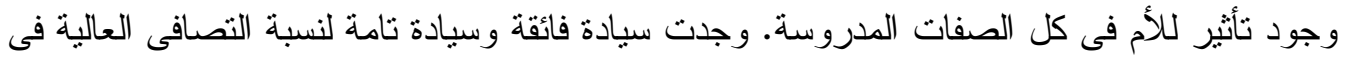

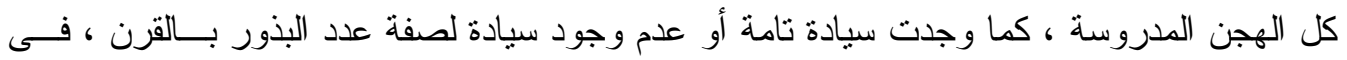
حين وجدت سيادة جزئية للأب المتأخر فى كل الهجن ، ووجدت سيادة للقرون الأطول ووزن البن البذرة

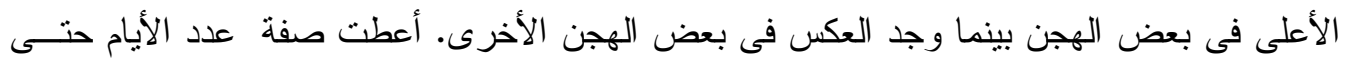

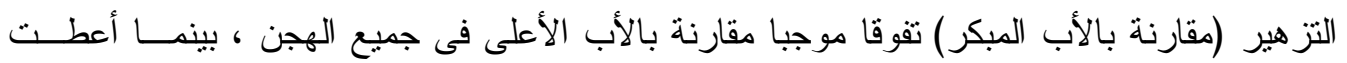

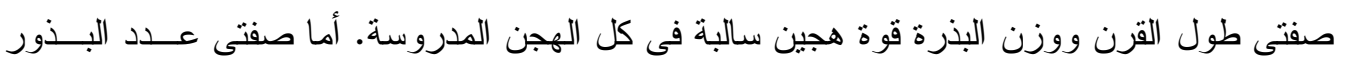

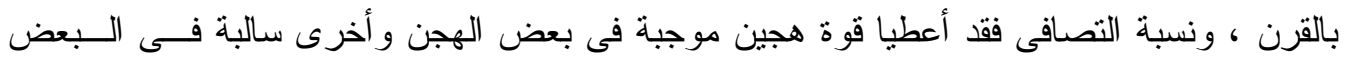

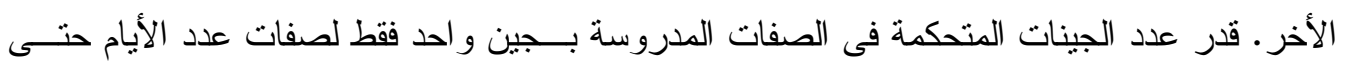

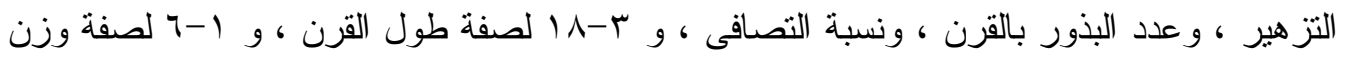

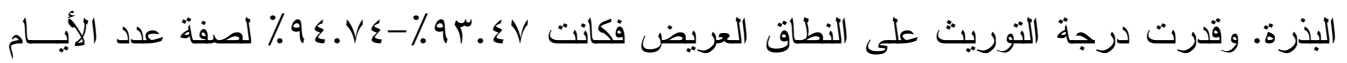

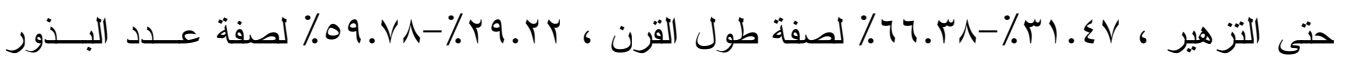

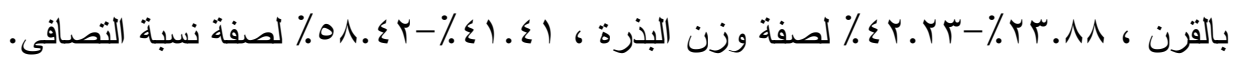

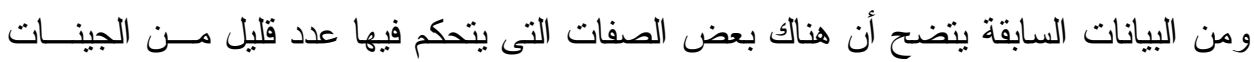

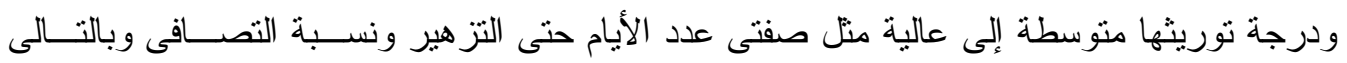

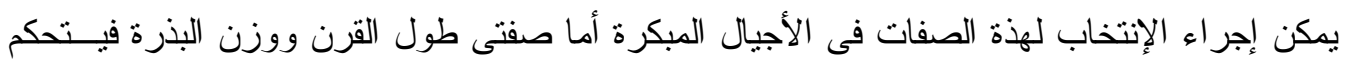

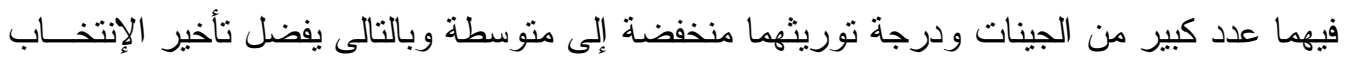
لهما للأجيال المتأخرة. 